\title{
THE WORLD TRADE ORGANIZATION (WTO) FREE TRADE WITHIN FAIR TRADE CHALLENGES
}

\author{
M. Ya'kub Aiyub Kadir* \\ International Law Department, Faculty of Law Universitas Syiah Kuala, Banda Aceh \\ Jalan T. Nyak Arief Darussalam, Banda Aceh 23111
}

\section{Intisari}

Free trade and fair trade are considered an ambiguous term with relative meanings of identification. $\mathrm{Ob}$ jectively, free and fair trade does not mean completely free and fair, but it means trade under binding rules obeyed by member countries as a consequence of their commitment after signing and ratification of the WTO agreements. Hence, this paper aims at exploring the issue and does an effort to harmonise between free trade and fair trade within the WTO system.

Keywords: WTO, free trade, fair trade.

\section{Intisari}

Perdagangan bebas dan perdagangan yang adil adalah dua istilah yang ambigu maknanya. Secara obyektif, perdagangan bebas tidak bermakna bebas dan adil seluruhnya, tetapi bermakna sebuah perdagangan di bawah aturan-aturan mengikat setelah negara anggota menandatangani dan meratifikasi kesepakatan WTO. Tetapi dalam realitas kebanyakan Negara, terutama negara berkembang tidak mampu untuk membuka pasar dan menurunkan tarif secara keseluruhan. Persoalan tidak berimbangnya kekuatan, kurang demokrasi, krisis legitimasi dan dobel standar dalam WTO sistem merupakan sebuah tantangan yang masih berlanjut. Paper ini akan mengkaji persoalan ini dan berupaya mengharmonisasikan antara perdagangan bebas dan adil dalam sistem WTO.

Kata Kunci: WTO, perdagangan bebas, perdagangan adil.

\section{Pokok Muatan}

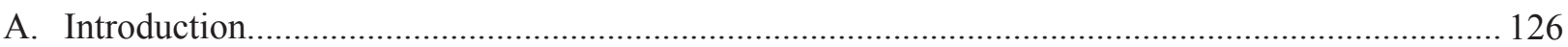

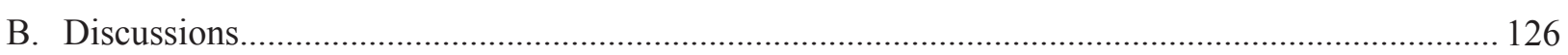

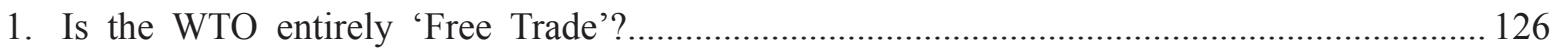

2. Whether the WTO is a System of Rules Dedicated to be Fair?.......................................... 128

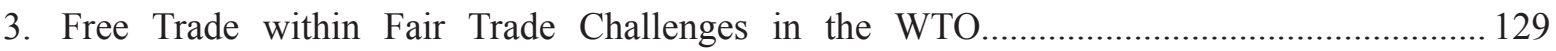

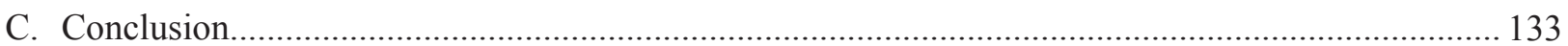

* Correspondence address: muyakadir@yahoo.com 


\section{A. Introduction}

The world trading system is represented by the World Trade Organization (WTO) ${ }^{1}$ that is set up to facilitate and govern the world trading system. The WTO was established on 1 January 1995 after signing the WTO agreement on April 1994 in Marakesh (Marocco). ${ }^{2}$ Philosophically, the aim of the WTO is to raise standards of living, ensuring full employment and a large and steadily growing volume of real income and effective demand, and expanding the production of and trade in goods and services, while allowing for the optimal use of the world's resources in accordance with the objective of sustainable development, seeking both to protect and preserve the environment and to enhance the means for doing so in a manner consistent with their respective needs and concerns at different levels of economic development. ${ }^{3}$

However, after about fifteen years of establishing the WTO, there are many issues concerned with the continuity of negotiation and the fairness of the game-rules in order to provide mutual benefits both to developed states and developing states around the world. The World Trade Organization (WTO) from the General Agreement on Trade and Tariffs (GATT) rules, as an agent of free trade, has changed several times related to the demand of fairness (development concerns) from developing countries. ${ }^{4}$ The aim is to give developing, ${ }^{5}$ and least developed countries preferential access to developed countries markets and the ability to protect their own market. So, they have some privileges from developed countries due to a low development and lack of technology in their countries. It is an exception to the basic GATT structure of nondiscrimination and reciprocity. ${ }^{6}$

Fairness and freedom of trade is still a controversial issue. The supporters consider that WTO will take the international community from poverty into sovereignty and prosperity. ${ }^{7}$ On the other hand, the opponents have completely opposed it due to their suspicion of neo-colonialism being a hidden agenda in it or in another word whether it is a 'free trade' with the negative impressions due to the negative impacts ${ }^{9}$ of its system or it is a system of rules dedicated to open and fair. This issue has been assumed more essential since the collapse of Cancun Ministerial Conference on September 2003 due to rejecting proposal from the developed countries by the developing countries. ${ }^{10}$ Therefore, this paper aims at examining the possibilities of correlation between free trade and fairness ${ }^{11}$ in the WTO system and also an autocratic toward the concepts themselves. $^{12}$

B. Discussion

\section{Is the WTO entirely 'Free Trade'?}

It is widely known that the WTO has brought

The abbreviation the WTO will be used in entire of this essay.

See the World Trade Organisation, "The WTO in Brief: Part 1, The Multilateral Trading System-Past, Present and Future", http://www.wto. org, accessed on 17 May 2013.

See the World Trade Organisation, "Uruguay Round Agreement, Marakesh Agreement Establishing the World Trade Organisation", http:// www.wto.org/english/docs e/legal e/04-wto e.htm\#article, accessed on 17 May 2013.

4 See a deep explanation from the International Institute for Sustainable Development, "Special and Differential Treatment", http://www.iisd. org/pdf/2003/investment sdc may 2003 2.pdf, accessed on 15 February 2011.

See "Ministerial Declaration", WT/MIN/01/DEC/1 20 Nov 2001 (01-58590) from Ministerial Conference, Fourth Session, at Doha 9-14 November 2001. This shows that most of the WTO member is the developing countries.

6 These two basic principles of the GATT have substantial problem in implementing fairness values. See the Preamble of the GATT in Basic Instruments and Selected Documents (B.I.S.D), Vol. IV, Geneva 1968, pp. 1-13.

Some scholars believe that Free Trade will give benefit to developing countries if they have good policy and ability to bargain. It seems that they partially supported the developed countries without considering the real process of world trade. See Shela Page et al., 1991, the GATT Uruguay Round: Effects on Developing Countries, Odi Special Report, London, pp. 34-40.

8 See Koalisi Ornop Pemantau WTO (KOP-WTO),'Indonesia Must Firmly Reject WTO Agreements that Are Detrimental to The People", www. peoplesfoodsovereignty.org/activity-02.htm., accessed on 27 July 2009.

9 The negative impacts of free trade can be seen from the descriptions regarding human rights, labour standard, women's right, basic need and social protection. See Loudes Beneria and Savitri Bisnath (Ed.) 2004, Global Tensions, Challenges and Opportunities in The World Economy, Routledge, New York and London, pp. 113-160.

10 See comprehensive information e.g. Action Aid International, "Beyond Cancun: Key Issues Facing the Multilateral Trading System", Action Aid International, December 2003, www.wto.org/english/forums_e/pospap38acton aid_e.doc, accessed on 26th January 2009.

11 Jeffrey L. Dunoff, "Is Free Trade Fair?", Paper, presented at the American Society of International Law Annual Meeting in Washington, D.C., April, 2003.

12 There are three underpinning aspects namely: Democracy, Accountability and Legitimacy, see Jeffrey L. Dunoff, Ibid., p. 2. 
a remarkable change in the international trading system. ${ }^{13}$ In particular, regarding free trade issue, it is a way to the substantial reduction of tariffs and other barriers to trade and to the elimination of discriminatory treatment in international trade relations. Its role can be seen as Jackson emphasised "The GATT/WTO was intended to reverse the protectionist and discriminatory trade practise that had multiplied during the pre- war depression years and designed to help the advanced industrial countries achieve the multiple objective of full employment, freer and expanding trade and stable exchange rate". 14

Free trade has been a common term without satisfied explanation due to the ambiguity of the meaning. It is being economic ideological struggle from the developed countries to get a new market in the other world. Free trade to some extent steadily become the misleading word for some people, and become a good opportunity to the others. Many partial explanations tend to bring the issue to be more complicated and more difficult to understand. ${ }^{15}$ The huge ambiguity in "Free Trade" terminology needs to a long explanation due to the euphoria of globalisation that deceive almost all the people in the world. What and where can be said 'free' if the system comprises with many provisions that created by the groups of the countries, which automatically can not be separated to their profits and interests. ${ }^{16}$
Even Sylvia Ostry has characterised the old GATT system as a 'bicycle built for two' with the United States in the front seat and the European Communities in the back. ${ }^{17}$ This supported the argument that the WTO basically is not designed to the fit of developing countries and least developed countries interests.

Therefore, Free trade merely a notion and interpreted by the developed countries in order to get free market for their goods and Services. However, the developing countries had to follow the rule under trapping of the term. Even though some experts still believe that the developing countries can get benefit from free trade system. Yet, in reality, the fair trade is still difficult to be proven objectively. Free trade regarded by Jackson as one of globalization pillars that bring the world to a small village, borderless. So the role of government is reduced in some extent. ${ }^{18}$ But in other side there is a double standard of the developed countries in order to get more benefit from developing countries. Bhagwati pointed that "The stone are to be thrown at the poor countries glass houses by the rich countries that build fortresses around their own". ${ }^{19}$

For example, many issues often blame the domestic policies of the developing countries as a argument to maintain the world order, as Hudec stated that the various of national domestic policies in trading seem to be causing the most significant

13 Even Condon states that the WTO has affected the major issue in our live, such as, aids, terrorism, illegal immigration. See Bradly J. Condom, 2002, NAFTA, WTO and Global Business Strategy: How Aids, Trade and Terrorism Affect our Economic Future, Quorum Books, London, pp.189-212.

14 J.H. Jackson, et al., 2002, Legal Problem of International Economic Relations, Cases, Materials, and Text, West Group, ST. Paul, Minn, pp. 200-201. See also Thomas and Meyer, 1997, The New Rules of Global Trade, A Guide to the WTO, Carswell, Canada, p. 2. and pp. $347-349$.

15 For example, Sokhom pointed out that Free Trade and GATT is itself in crisis due to not concern to agricultural and service sector. See Sovathana Sokhom, "The Trade War of the Twenty-First Century" in Moncarz R. (Ed.), 1995, International Trade and The New Economic Order, Pergamon, UK., p. 124.

16 See the interests of the groups of countries in background of the WTO, provisions regarding accession procedures, decisions making, amendments the WTO rules, Dispute Settlement in Mitsuo Matsushita et al., 2003, The World Trade Organization, Law, Practice, and Policy, Oxford University Press, London, pp. 2-14. Regarding problems of membership and accession in the WTO, see Carlos A. Magarinos et al. (Ed.), 2002, China in the WTO, The Birth of New Catching-up Strategy, Palgrave Macmillan, Hampshire, pp.1-24. Regarding dispute settlements that still largely the province of the rich, see Kara Leitner and Simon Lester, "WTO Dispute Settlement 1995-2002, A Statistical Analysis", Journal of International Economic Law, Vol. 6, No. 1, March 2003, pp. 259-260.

17 See Sylvia Ostry, “The Uruguay Round North-South Bargain: Implication for Future Negotiation” in Daniel L.M. Kennedy and James D. Southwick (Ed.), 2002, The Political Economy of International Trade Law, Essay in Honor Of Robert E.Hudec, Cambridge University Press, Cambridge, pp. 299-300.

18 J.H. Jackson, et al., Loc.cit. See also Thomas and Meyer, Op.cit., p. 2 and p. 209.

19 See how the developed countries blame the developing countries, although transgression are to be found in the developed countries like in prohibiting child labour, See J. Bhagwati, 1995, Free Trade, 'Fairness', and The New Protectionism, Reflection on an Agenda for the World Trade Organization, The Institute of Economic Affairs for the Wincott Foundation, London, pp. 31-32.

20 Low Labour standard in developing countries give much profits to the developed countries, as a result this become an issue of unfairness; see 
problems in international trade relation, particularly environmental policy, labour policy ${ }^{20}$ and competition policy. ${ }^{21}$ Moreover, there are those who consent to pure free trade without any Special and Preferential Policy for the developing countries. ${ }^{22}$ Free trade entails the elimination of any various form of discrimination between national economies. ${ }^{23}$ It has caused countries could easily invest and export goods and service to other countries and in adverse. The problem emerges when standard of countries different, particularly in environment, labour and competition. ${ }^{24}$ Each country seeks a high benefit without paying attention to the others. So the issue of unfairness was conceived, for example, environmental problems including health, safety regulations and mistreatment of animal. The problem arises when producers in high standard countries complaint about an adverse effects and cost advantages for producers in low standard countries. It causes economic injuries to producers and workers. Moreover, Bhagwati explained the fairness problem dealt with difficulties in monitoring of one's firm in foreign country and country with lower standard may object on grounds of "National sovereignty." 25

\section{Whether the WTO is a System of Rules Dedicated to be Fair?}

Although many dissolutions on the WTO system, particularly from developing countries, has been going on due to legalisation from the powerful countries. However, the Fairness Norms might be are questioned in two kinds, as follow: Firstly, the weaknesses of regulatory policies in other countries give the exporters of those countries an unfair advantage when they enter another country's market. These complaints usually labelled as "Social Dumping" or "Regulatory Subsidies". Secondly, the unfairness claims made against foreign laws, practice and institutions that impede one's own export to foreign markets. ${ }^{26}$ Fairness concern to the ability of a country to feel and take in charge to the weaknesses of other countries. Hudec gave a good statement regarding fairness in the WTO: ${ }^{27}$

All nations have a tendency to distort the norms of fairness they apply to other countries. They assume that what they do at home is normal, natural, and pleasing to God, while at the same time feeling perfectly free to criticize superficially different practise of others that are no rationale way distinguishable from their own.

Historically, the "Birth Defects" 28 of the GATT has influenced the flaw in the WTO. Consequently, the struggle to fairness in free trade has not yet implemented instead of saying that the free and fairness is still jargon which do not have a substantial meaning. The world economic order which merely reserve to $20 \%$ world population and disregard the $80 \%$ as the rests became a measure to look at the notion of the fairness issues. The developing countries and the least developed countries being trapped in the ship driven by the developed countries. ${ }^{29}$ Moreover, Debra P. Steger emphasized some reasons of flaws in the WTO: ${ }^{30}$

Ozey Mehmet et al., 1999, Toward a Fair Global Labour Market, Avoiding a New Slave Trade, Routledge, London and New York, p. 70.

21 See Jaghdish Bhagwati and Robert E. Hudec, 1996, Fair Trade and Harmonization: Prerequisites for Free Trade?, MIT, USA, pp. 1-5.

22 The Special and Differential Treatment is off benefit to developing countries. See Hunter Nottage, "Trade and Competition in the WTO, Pondering the Applicability of Special and Differential Treatment", Journal of International Economic Law, Vol. 6, Issue 1, March 2003, pp. 23-47.

23 Andree Sapir "Trade Liberalization of Social Policies, Lessons from European Integration” in Bhagwati, J and Hudec R., Op.cit, p. 179.

24 Bhagwati suggested to shape new leadership in the WTO "[...] intellectual leadership, not the skill of political fixmanship". See Jagdish Bhagwati, Op.cit., p. 11.

25 Jaghdish Bhaghwati. and Robert E. Hudec, Op.cit., p.16. Also in another book Bhagwati describe a Globalization as "The Wind of the Hundred Days" that explored how social agenda can not be adopted in free trade process. See Baghwati, 2000, The Wind of the Hundreds Days: How Washington Mismanaged Globalization, MIT, USA, pp. 65-137.

26 Bhagwati and TN Srinivan, "Trade and Environment: Does Environmental Diversity Detract from the Case for Free Trade?", in Jaghdish Bhagwati and Robert Hudec, Loc.cit., p. 12.

Jaghdish Bhaghwati and Robert E. Hudec, Loc.cit., p.16.

The term used by Professor Jackson, See complete explanation in Mitsuo Matsushita et al., Op.cit., p. 3.

29 See a whole speech from Fidel Castro Ruz, "Neo-Liberal Globalisation and The Third World", www.come.to/indomarxist.com, accessed on 14th January 2008

30 Debra P. Steger, "The Culture of the WTO: Why it needs to Change", in William J. Davey and John Jackson (Ed.) 2008, The Future of International Economic Law, Oxford University Press, London, pp. 47-48. 
The mandate and purpose of the WTO is no longer clear. The mandate of the GATT system was continuing the process of trade liberalisation-reducing barriers to trade in order to encourage economic growth that would bring greater wealth and prosperity. The preamble to the GATT 1974 reflected these goals. The preamble of the WTO agreement is broader-it includes the goals of environmental sustainability and development. These new goals have been recognised by the appellate Body and the dispute settlement bodies, but they have not become part of the accepted theology or culture of the WTO as perceived by its members [...]. And there is a difference between the actual procedures of the WTO for decision making and rule making, and the practice of the members in taking decisions.

Fairness entails both a procedural element that related to questions of due process and a chance to be heard, as well as a substantive element that asks whether the burdens and benefits of governance are being distributed in ways that meet agreed upon equity norms. Embedded in the question of substantive fairness is a great deal of scope for normative disputes. As governance moves into the supranational realm and values diverge, the potential for perceived unfairness grows.

No structure of administrative law guarantees substantive fairness. But procedures that give all interested parties a chance to be heard and provide for careful deliberation are likely to generate outcomes that will be considered fair. Once again, the WTO has some distance to go in developing administrative structures that offer these elements. The Doha round was launched with an emphasis on the needs of the developing world, there is no doubt that the outcomes of past rounds of negotiation have not always put the needs of developing countries first. While the WTO's consensus based policy making has certain advantages, it gives particular weight to the strongest countries. In addition, Amrita Narlikar points to three problems associated with consensus policy making, that are, lack of representation for some least developed countries, intimidation of least developed countries by developed countries, and exclusion of least developed countries in 'Green Room' meeting. ${ }^{31}$

\section{Free Trade within Fair Trade Challenges in the WTO}

The controversy between free trade and fair trade, ${ }^{32}$ can be seen from diversity of world societies that can not be unified in the same rules. Maduro emphases that "it is a reflection of the social self determination of the different political communities and it is considered as ideological rhetoric". ${ }^{33} \mathrm{He}$ argues that either the policies of the free trade or the policies of fair trade challenge the social self-determination of their political communities, so how to balance the economic gains of free trade with the social values inherent in the ideals of fair trade. ${ }^{34}$ It needs a good effort to bring free trade and social right simultaneously.

It seems reasonable to look at to what extend it can be called as free trade or fair trade. There are many reasons ${ }^{35}$ to observe the WTO concerning the free trade and fairness. Some of them are: ${ }^{36}$

a. The WTO is a new international institution, which still needs more feedback in order to embodying its goal in the real world. As stated by Jackson,

31 Amrita Narlikar, 2006, Fairness in International Trade Negotiation: Developing Countries in the GATT and WTO, Wiley-Blackwell, Oxford, pp.1014-1015.

32 Bhagwati said that "Fairness, like beauty, is in the eye of the beholder". See Jaghdish Bhaghwati and Robert E. Hudec (Ed.), 1996, Fair Trade and Harmonization: Prerequisites for Free Trade?, Vol. II, MIT, p. 10.

33 Maduro, M.P., 2001,"Is There Any Such Thing as Free Trade or Fair Trade" A Constitutional Analyses of Their Impact of International Trade on the European Social Model" in Burca \& Joanna Scott, 2001, The EU and The WTO: Legal and Constitutional Issues, Hart Publishing, Oregon, p. 258.

34 Ibid.

35 Compare with "10 Common Misunderstandings about the WTO". This article contains contra arguments toward 10 misunderstanding about the WTO; unfortunately, it is not enough evident to support it. World Trade Organization, "10 Common Misunderstandings about the WTO", www. Wto.org/English/res_e/doload_e/10mis_e.pdf, accessed on 6 June 2009.

36 See John H. Jackson, 2000, The Jurisprudence of GATT and The WTO, Insights on Treaty Law and Economic Relations, Cambridge University Press, Cambridge, pp. 410-411. 
the WTO is still "a modest step forward with regard to the institutional structure". 37

b. The background of WTO as the successor $^{38}$ of GATT is dominated by the developed countries and their interests. Therefore, there are assumptions that WTO is merely an extension of the developed countries and huge trans-national companies. It was supported by Rugman that "The reality of the WTO is that it is a bargaining forum dominated by the US and Western Europe. ${ }^{39}$

c. Social, labour and environmental problems regarding free trade are an urgent issue nowadays due to overwhelming profit interest from a wide market which was restricted before.

d. The developing countries have still undergone difficulties in representing their economic interests and using their rights as the members of WTO in comparison to developed countries that have more powerful and well-prepared delegations. ${ }^{40}$

e. Free trade as a highlight point of the WTO is a universal agenda that still has basic problems among the countries in 'justice' frame.

f. It is an assumption that there is an overlapping role between the WTO and the United Nations Conference on Trade and Development (UNCTAD) ${ }^{41}$ in ordering trade regulation among countries.

g. According to Makuch, ${ }^{42}$ this institution has experienced a closed system since its ancestor General Agreement on Tariffs and Trade (GATT) was established in 1947, so he hopes wide changes will be carried out toward a more open and beneficial situation to the others.

Narakar believed that the bargaining coalitions of Developing Countries in the GATT and WTO, from 1982 to present days, with focus through the Uruguay Round as a case study shown that the developing countries ${ }^{43}$ have difficulties in making coalition before negotiation which is influenced both in internal coherence and external weight before they can reach the stage of bargaining. The different of interest of each countries, as well as identity should seek an appropriate type of coalition. The sustainability and effectiveness is two key factors that she suggested to be found in each coalition in order to reach optimal advantages. ${ }^{44}$

Free trade is a fault theory of misunderstanding of freedom. Non-tariff policy is not always use-

Ibid. p. 411. Irwin also stated that "The World Trading System is Far from Perfect, and Many Reforms and Changes in Rules Should be Under Discussion". See Douglas A. Irwin, 2002, Free Trade Under Fire, Princeton University Press, the UK, p. 228.

38 Apposes the popular belief that the WTO replaced the GATT due to an amended GATT remains is one of legal pillars of the world's trade and investment systems, see Alan M. Rugman, "The World Trade Organization and the International Political Economy" in Alan M. Rugman and Gavin Boyd (Ed.), 2001, The WTO in the New Global Economy, Trade and Investment Issues in the Millennium Round, Edwar Elgar, UK, p. 3.

39 Alan M. Rugman, "The World Trade Organization and the International Political Economy” in Alan M. Rugman and Gavin Boyd (Ed.), Ibid., p. 6 .

40 According to Amrita Narikar, there are four pillars underlying WTO decision-making processes: one-member-one-vote principle, consensusbased voting, member-driven character, and the importance of informal processes, these latter three caused the developing countries have found many difficulties in meeting processes, see Amrita Narikar, "WTO Decision-Making and Developing Countries", http://www.southcentre.org/ info/southbulletin/bulletin26/bulletin2, accessed on 27 July 2009.

41 The United Nations Conference on Trade and Development (UNCTAD) is the principal organ of the General Assembly in the field of trade and Development. It was established as a permanent intergovernmental body in 1964 in Geneva, in order to accelerating economic growth and development, particularly, that of the developing countries. See Mahomet Arda, "The United Nations Conference on Trade and Development" in Jacob Wersment, 1996, Greening International Institution, Earthscan Publication Ltd., London, p. 71.

42 Zen Makuch, "The World Trade Organization General Agreement on Tariffs and Trade", in Jacob Werksmen, Ibid., p. 94.

43 There are no the WTO definition of "Developing Countries" or "Developed Countries" for "Developing Countries" there is a degree of self selection, whereas "Least Developed Countries" are defined to the UN list, namely 49 countries, among them: Afghanistan, Angola, Bangladesh, Benin, Bhutan, Burkina Faso, Burundi, Cambodia, Cape Verde, Central African Republic, Chad, Comoros, etc. See UNCATD, "Least Developed Countries", www.unctad.org/templates/countries.asp?intltemID, accessed on 6 September 2008.

44 See Amrita Narlikar, 2003, International Trade and Developing Countries, Bargaining Coalitions in the GATT \& WTO, Routledge, USA and Canada, p.197.

45 See James H. Mathis, 2002, Regional Trade Agreements in the GATT/WTO, Article XXIV and The Internal Trade Requirement, T.M.C. Asser Press, The Hague, The Netherlands.

46 The core problems remain unresolved, such as perennial problem of unemployment, underemployment, growth and development, trade, sovereign debt, regional integration etc. See Raul Moncarz (Ed.) 1995, International Trade and The New Economic Order, Pergamon, UK, pp.1-2. 
ful if domestic rules are not sufficient enough. We need to consider that we are not the same condition but the same right to life. Every country has its own characteristics. Therefore, it is highly worthy to give any preference to such countries. Even discrimination is regarded as fairness in many cases, due to differentiations among countries. ${ }^{45}$ The failure of scholars in understanding the realities has been widened the gap between fairness and free trade in one side with the reality of world trade in another side. ${ }^{46}$ Even, such as Thabo Mbeki, the president of South Africa pointed out that "Free trade system might perpetuate global apartheid that locks certain people into a position of poverty, unequally and disenfranchisement, the accident of birth into particular nationality has affected to the life opportunities". ${ }^{47}$ Daniel C. Esty stated that: ${ }^{48}$

Of particular concern is the participation of developing countries. While the Doha Round was launched with an emphasis on the needs of the developing world, there is no doubt that the outcomes of past rounds of negotiations have not always put the needs of developing countries first. While the WTO's consensus based policy-making has certain advantages, it gives particular weight to the strongest countries.

While Amrita Narlikar pointed out to three problems associated with consensus policy making: lack of representation for some least developed countries, intimidation of least developed countries by developed countries, and exclusion of least developed countries in "Green room Meeting". 49 From the rubble of Doha, a new world trade system needs to be built on the principle of fair trade, not free trade. If we really want to end an extreme po- verty, then we need to open up the markets of rich countries, while allowing poor countries to protect and subsidize theirs. It is the recipe that ensured the least advantaged states today, are not hungry and tilling the fields. ${ }^{50}$ Before a country pushes its infant industries on to the world market, it needs to train them initially. Nokia, Samsung and Toyota are all had to be cushioned with subsidies and tariffs for decades before they become big companies. In addition, the WTO should design and implement free trade depend on countries interests, to establish physical infrastructure that positively affect the capacity to export, supporting national institutions to maintain quality standards and provide finance, insurance and marketing for export, and appropriate safety nets to ensure that trade reform may benefit the country as a whole, in particular the poor countries. $^{51}$

As an example, Britain was a backward rural country dependent on exporting raw wool. Turning that wool profitably into clothes happened elsewhere. Henry VII wanted Britain to set up manufacturing bases, and banned the export of wool, so clothes were manufactured in the UK. It is usually called protectionism. His successors kept it up by 1820 , the average tariff rate was 50 per cent. Within a century, protected British industries had spurted ahead of their European competitors. So the walls could finally be dismantled. Moreover, Dr Ha-Joon Chang, a South Korean economist at Cambridge University, explains in his book Bad Samaritans: "The Korean state nurtured certain new industries selected by the government through tariff protection, subsidies and other forms of government support, until they 'grew up' enough to withstand international competition." They owned all the banks;

\footnotetext{
47 See Joel P. Trachman, "Legal Aspects of a Poverty Agenda at the WTO: Trade Law and 'Global Apartheid", Journal of International Economic Law, Vol. 6, No. 1, March 2003, p. 4.

48 Daniel C. Esty, "Good Governance at The WTO: Building a Foundation of Administrative Law", in William J. Davey and John Jackson, (Ed), 2008, The Future of International Economic Law, Oxford University Press, Oxford, p. 85.

49 Amrita Narlikar, Op.cit., pp. 1014-15.

50 See Johann Hari, "Do You Want Free Trade or Fair Trade that Helps The Poor?", http://www.independent.co.uk/opinion/commentators, accessed onDecember 2009

51 See Constantine Michalopoulos, 2001, Developing Countries in the WTO, Palgrave, London, pp. 248-249.

52 See Johann Hari, "Do You Want Free Trade or Fair Trade that Helps The Poor?", http://www.independent.co.uk/opinion/commentators, accessed on 1 December 2009.

53 See Martin Vender Weyer, “Can Free Trade be Fair Trade?”, http://www.globalpolicy.org/component/content/article/220/47253.html, accessed
} on 1 December 2009. 
they controlled foreign investment tightly. The state controlled and guided the economy to the international market place. ${ }^{52}$

That free trade need times to develop as it viewed from some examples, such as: in year 2000, every cow in the European Union received the equivalent of $\$ 913$ in subsidy, while every subSaharan African received \$ 8 in EU aid. Two-fifths of the entire EU budget goes on subsidising farmers and putting food producers everywhere else in the world at an unfair disadvantage, except possibly American farmers, who are themselves comfortably protected by a $\$ 180$ subsidy deal which also brought in by George W Bush in 2002. ${ }^{53}$ Fair Trade should involve the following principles: ${ }^{54}$

a. Producers receive a fair price of living wage. For commodities, farmers receive a stable, minimum price.

b. Forced labour and exploitative child labour are not allowed.

c. Buyers and producers trade under direct long-term relationships.

d. Producers have access to financial and technical assistance.

e. Sustainable production techniques are encouraged.

f. Working conditions are healthy and safe.

g. Equal employment opportunities are provided for all.

h. All aspects of trade and production are open to public accountability.

Another issues like the accession of small vulnerable states to the WTO like Vanuatu as they would not be able to negotiate improved market access for their limited range of exports. However, there are numerous reasons why small developing countries choose to undergo the difficult and intrusive process of accession that are specific to the geopolitics of their region. The experience of small vulnerable states with the rules-based multilateral system has not been an entirely happy one. ${ }^{55}$

While especially developed country negotiators would describe the purpose of the WTO as solely dedicated to trade liberalisation, it is clear that the developing country members of the WTO also view development as a key goal of the organisation. According to Debra S. Steger, there is presently, it is fair to say, no common understanding on what the mandate of WTO is. However if one take into account the views of two-third of its membership, it is clear that the WTO serves the development agenda, and is no longer solely concerned with the goal of accelerating trade liberalization. Taking into consideration the broad scope of many of the WTO agreements, and the topics being discussed in WTO committees and councils as well as in the Doha round negotiations, the rule clearly affect regulation of the environment, public health, service, investment and intellectual property as well as trade. ${ }^{56}$

Debra Steger notes that the culture of the WTO stems from that of GATT and catalogs a number of problems that it has required changing. She reviews in that regard several proposals for reform from Russian president Putin's recent call for a new international trade organization to the more detail analyses on reform contained in the WTO's Sutherland report and the Atlantics council's report on the transatlantic leadership in the new global economy. ${ }^{57}$

In addition, the international fair trade movement ${ }^{58}$ is pushing for new rules to protect marginalised producers. Free trade and fair trade seem two incompatible visions. Supporters of fair trade say that exchanges between developed and the less

\footnotetext{
54 See Global Exchange, "Understanding Fair Trade", http://www.globalexchange.org/campaigns/fairtrade, accessed on 1 December 2009.

55 See completely Roman Grynberg (Ed.), 2006, WTO at the Margins, Small States and the Multilateral Trading System, Cambridge University Press, Cambridge, pp. 1-8.

56 Debra P. Steger, "The Culture of the WTO: Why it Needs to Change", in William J. Davey and John Jackson (Ed.), 2008, The Future of International Economic Law, Oxford University Press, Oxford, pp. 45-57.

Ibid.

58 The four associations are based mostly in Europe, but their members represent many southern producers and distributors. They are the Netherlands based International Fair Trade Association (IFAT), the Germany based Fair Trade Labelling Organisations International (FLO-I), the Network of European Worldshops (NEWS!) representing approximately 2,500 fair trade shops, and the European Fair Trade Association (EFTA), with a special advocacy office in Brussels, See Jason Nardi, "WTO-Special: Free Trade or Fair Trade", http://ipsnews.net/news. asp? idnews $=31371$, accessed on 1 December 2009 .
} 
developed countries take place on uneven terms, and should be made more equitable by protecting the weaker countries. Free traders maintain that in the long run markets will correct the imbalance, and both rich and poor countries will benefit from full access to each others' markets. In this way, free traders hold that free trade is fair trade. The fair trade movement also believes that rich countries have a moral obligation to stop all forms of tradedistorting subsidy and dumping on world markets, as the impact of these practices on the poorest has been devastating. ${ }^{59}$

As a supporter of fair trade, Paolo Pastore, Director of Transfair Italy (a certifier of fair trade products, and member of FLO-I) is against certification of a single product, which he says can lead to whitewashing of an otherwise unverified company. More than 4,000 small-scale and marginalised producer groups and hundreds of thousands of workers in more than 50 developing countries are said to participate in fair trade supply chains. More than five million people in Africa, Latin America and Asia benefit from fair trade terms, fair trade promoters say. Most of this trade is in traditional commodities produced by small farmers or crafts people. In a controversial move, some multinational companies have also begun marketing under fair trade labels. ${ }^{60}$

\section{Conclusion}

Free trade as an instrument of globalization is an ambiguous term with relative meanings of identifications. Objectively, this is not meant completely free and fair. There are binding rules should be obeyed by parties. However, in fact, this ideal aims is still far away. Many developing and least developed countries are not able to compete to the developed countries. Moreover, the contentious issue regarding unbalancing powers, lack of democracy, crisis of legitimacy and double standard in the WTO system has not yet well-resolved. This issue can not be denied since the stagnancy of development or even many disadvantages suffered by the third world during involving in the WTO system. The solution is most depended on the good will from the developed countries to help the others as well as the efforts of the developing states to strengthen the bargain and commit to help the poor people in their own countries. It might be another way out that regional trade organization representing the developing countries and the least-developed countries in order to embodying fair trade in the frame of free trade. It is not a suspicion that the developed countries have used the WTO as a bridge to implement their economic and political interests over the world. Somehow, the prosperity of people in the world should be a common goal of the WTO's countries. Free trade and fair trade should not be competed to each other; it would be a coin with two faces. Free trade should become fair and fair trade would be existed in free trade. Many development programs become a pillar to harmonise this constrain. So, the WTO should belong to "fair trade' in order to apply 'free trade' on the earth. It is recommended to design and implement trade policy in the WTO depending on countries interests and abilities, to establish physical infrastructure that affect the capacity to export, to support institutions for maintaining quality standards and providing finance, insurance and market for export, to set up appropriate safety nets to ensure trade reform benefits countries as a whole, in particular within the developing and the less developed countries.

\section{REFERENCES}

A. Book

Beneria, Loudes and Savitri Bisnath (Ed.) 2004, Global Tensions, Challenges and Opportunities in The World Economy, Routledge, New
York and London.

Bhagwati, Jaghdish, 1995, Free Trade, 'Fairness', and The New Protectionism, Reflection on an Agenda for the World Trade Organization,

See Jason Nardi, Ibid.,

60 The Swiss firm Nestlé has launched a fair trade certified coffee branded 'Partners' Blend' that comes from five small producers cooperatives in Ethiopia and El Salvador. See Jason Nardi, Ibid. 
The Institute of Economic Affairs for the Wincott Foundation, London.

Bhagwati, Jaghdish and Robert E. Hudec, 1996, Fair Trade and Harmonization: Prerequisites for Free Trade?, MIT, USA.

Baghwati, Jaghdish, 2000, The Wind of the Hundreds Days: How Washington Mismanaged Globalization, MIT, USA.

Condom, Bradly J., 2002, NAFTA, WTO and Global Business Strategy: How Aids, Trade and Terrorism Affect our Economic Future, Quorum Books, London.

Grynberg, Roman (Ed.), 2006, WTO at the Margins, Small States and the Multilateral Trading System, Cambridge University Press, Cambridge.

Irwin, Douglas A., 2002, Free Trade Under Fire, Princeton University Press, UK.

Jackson, John H., 2000, The Jurisprudence of GATT and The WTO, Insights on Treaty Law and Economic Relations, Cambridge University Press, Cambridge.

Jackson, J.H., et al., 2002, Legal Problem of International Economic Relations, Cases, Materials, and Text, West Group, ST. Paul, Minn.

Magarinos, Carlos A. et al. (Ed.), 2002, China in the WTO, The Birth of New Catching-up Strategy, Palgrave Macmillan, Hampshire.

Mathis, H., James, 2002, Regional Trade Agreements in the GATT/WTO, Article XXIV and The Internal Trade Requirement, T.M.C. Asser Press, The Hague, The Netherlands.

Matsushita, Mitsuo et al., 2003, The World Trade Organization, Law, Practice, and Policy, Oxford University Press, London.

Mehmet, Ozey et al., 1999, Toward a Fair Global Labour Market, Avoiding a New Slave Trade, Routledge, London and New York.

Michalopoulos, 2001, Developing Countries in the WTO, Palgrave, London.

Moncarz, Raul (Ed.) 1995, International Trade and The New Economic Order, Pergamon, UK.

Narlikar, Amrita, 2003, International Trade and
Developing Countries, Bargaining Coalitions in the GATT \& WTO, Routledge, USA and Canada.

Narlikar, Amrita, 2006, Fairness in International Trade Negotiation: Developing Countries in the GATT and WTO, Wiley-Blackwell, Oxford.

Page, Shela et al., 1991, the GATT Uruguay Round: Effects on Developing Countries, Odi Special Report, London.

Thomas and Meyer, 1997, The New Rules of Global Trade, A Guide to the WTO, Carswell, Canada.

Wersment, Jacob, 1996, Greening International Institution, Earthscan Publication Ltd., London.

\section{B. Antology}

Esty, Daniel C., "Good Governance at The WTO: Building a Foundation of Administrative Law", in William J. Davey and John Jackson, (Ed), 2008, The Future of International Economic Law, Oxford University Press, Oxford.

Maduro, M.P., 2001, "Is There Any Such Thing as Free Trade or Fair Trade A Constitutional Analyses of Their Impact of International Trade on the European Social Model" in Burca \& Joanna Scott, 2001, The EU and The WTO: Legal and Constitutional Issues, Hart Publishing, Oregon.

Ostry, Sylvia, "The Uruguay Round North-South Bargain: Implication for Future Negotiation" in Daniel L.M. Kennedy and James D. Southwick (Ed.), 2002, The Political Economy of International Trade Law, Essay in Honor of Robert E. Hudec, Cambridge University Press, Cambridge.

Rugman, Alan M., "The World Trade Organization and the International Political Economy" in Alan M. Rugman and Gavin Boyd (Ed.), 2001, The WTO in the New Global Economy, Trade and Investment Issues in the Millen- 
nium Round, Edwar Elgar, UK.

Sokhom, Sovathana, "The Trade War of the Twenty-First Century" in Moncarz R. (Ed), 1995, International Trade and The New Economic Order, Pergamon, UK.

Steger, Debra P., "The Culture of the WTO: Why it Needs to Change", in William J. Davey and John Jackson (Ed.) 2008, The Future of International Economic Law, Oxford University Press, London.

\section{Journal Articles}

Leitner, Kara and Simon Lester, "WTO Dispute Settlement 1995-2002, A Statistical Analysis", Journal of International Economic Law, Vol. 6, No. 1, March 2003.

Nottage, Hunter, "Trade and Competition in the WTO, Pondering the Applicability of Special and Differential Treatment", Journal of International Economic Law, Vol. 6, Issue 1, March 2003.

Trachman, Joel P., "Legal Aspects of a Poverty Agenda at the WTO: Trade Law and 'Global Apartheid", Journal of International Economic Law, Vol. 6, No. 1, March 2003.

\section{Seminars and Workshop}

Dunoff, Jeffrey L., "Is Free Trade Fair?", Paper, presented at the American Society of International Law Annual Meeting in Washington, D.C., April 2003.

\section{E. Internet Articles}

Action Aid International, "Beyond Cancun: Key Issues Facing the Multilateral Trading System", www.wto.org/english/forums_e/pospap38acton aid_e.doc, accessed on 26 January 2009.

Global Exchange, "Understanding Fair Trade", http://www.globalexchange.org/campaigns/ fairtrade, accessed on 1 December 2009.

Hari, Johann, "Do You Want Free Trade or Fair Trade that Helps The Poor?", http://www.independent.co.uk/opinion/commentators, ac- cessed on 1 December 2009.

Koalisi Ornop Pemantau WTO (KOPWTO),'Indonesia Must Firmly Reject WTO Agreements that Are Detrimental to The People", www.peoplesfoodsovereignty.org/ activity-02.htm., accessed on 27 July 2009.

Nardi, Jason, "WTO-Special: Free Trade or Fair Trade", http://ipsnews.net/news. asp? idnews $=31371$, accessed on 1 December 2009.

Narikar, Amrita, "WTO Decision-Making and Developing Countries", http://www.southcentre.org/info/southbulletin/bulletin26/bulletin2, accessed on 27 July 2009.

Weyer, Martin Vender, "Can Free Trade be Fair Trade?", http://www.globalpolicy.org/component/content/article/220/47253.html, accessed on 1 December 2009.

World Trade Organisation, "The WTO in Brief: Part 1, The Multilateral Trading SystemPast, Present and Future", http://www.wto. org, accessed on 17 May 2013.

World Trade Organisation, "Uruguay Round Agreement, Marakesh Agreement Establishing the World Trade Organisation", http://www. wto.org/english/docs_ellegal_e/04-wto_e. htm\#article, accessed on 17 May 2013.

World Trade Organization, "10 Common Misunderstandings about the WTO", www.wto.org/ English/res_eldoload_e/10mis_e.pdf, accessed on 6 June 2009.

Ruz, Fidel Castro, "Neo-Liberal Globalisation and The Third World", www.come.to/indomarxist.com, accessed on 14 January 2008.

The International Institute for Sustainable Development, "Special and Differential Treatment", http://www.iisd.org/pdf/2003/investment_ $s d c \_m a y \_2003 \_2 . p d f$, accessed on 15 February 2011.

UNCATD, "Least Developed Countries", www.unctad.org/templates/countries. asp?intltemID, accessed on 6 September 2008. 


\section{F. Others Document}

Ministerial Declaration", WT/MIN/01/DEC/1 20 Nov 2001 (01-58590) from Ministerial Conference, Fourth Session, at Doha 9-14 November 2001.
The Preamble of the GATT in Basic Instruments and Selected Documents (B.I.S.D), Vol. IV, Geneva 1968. 